\begin{tabular}{|c|c|c|}
\hline & $\begin{array}{c}\text { DWIJA CENDEKIA: Jurnal Riset Pedagogik 3 (2) (2019) 257-263 } \\
\text { DWIJA CENDEKIA } \\
\text { Jurnal Riset Pedagogik }\end{array}$ & $\begin{array}{l}=-1 \\
\text { DWIJA } \\
\text { CENDEKIA }\end{array}$ \\
\hline $\begin{array}{l}\text { UNIVEESSITAS } \\
\text { SEBELAS MARET }\end{array}$ & https://jurnal.uns.ac.id/jdc & \\
\hline
\end{tabular}

\title{
Meningkatkan Motivasi Belajar Bahasa Indonesia SD Menggunakan Google Classroom
}

\author{
Wahyu Nuning Budiarti
}

Universitas Nahdlatul Ulama Al Ghazali Cilacap

wahyununing.pgsd@unugha.ac.id

\section{Sejarah Artikel}

diterima 31/10/2019

disetujui 04/11/2019

diterbitkan 14/12/2019

\begin{abstract}
Using a smartphone now makes us unable to separate it in everyday life, not only adults, the generation born with technology that has developed very rapidly are children who are still in elementary school level. They are very familiar with smartphones. The smartphone application referred to here is Google Classroom. In addition to saving paper, the use of Google Classroom can invite students to make good use of smartphones. Indonesian is also a subject that can be integrated with all subjects in elementary school. Therefore an increase in motivation to learn Indonesian is needed in learning. The research method is Classroom Action Research, with the results of research that the use of Google Classroom is proven to increase student motivation to increase with the supervision of parents in doing assignments. Conclusion if we can not limit students using smartphones, then we must begin to integrate into learning, so that the use of smartphones is more beneficial for their lives as students.
\end{abstract}

Keywords: smartphone, google classroom, classroom action research, motivation to learn

\begin{abstract}
Abstrak
Penggunaan smartphone saat ini tidak dapat kita pisahkan dalam kehidupan sehari-hari, tidak hanya orang dewasa, generasi yang terlahir dengan teknologi yang sudah berkembang dengan sangat pesat adalah anak-anak yang masih berada di tingkat Sekolah Dasar. Mereka sudah sangat mengenal smartphone. Aplikasi smartphone yang dimaksud disini adalah Google Classroom. Selain hemat kertas, penggunaan Google Classroom ini dapat mengajak peserta didik supaya dapat memanfaatkan smartphone dengan baik. Bahasa Indonesia juga merupakan mata pelajaran yang dapat terintegrasi dengan semua mata pelajaran yang ada di Sekolah Dasar. Oleh karena itu peningkatan motivasi belajar Bahasa Indonesia dibutuhkan di dalam pembelajaran. Metode penelitian adalah Penelitian Tindakan Kelas, dengan hasil penelitian bahwa penggunaan Google Classroom terbukti dapat meningkatkan motivasi belajar siswa meningkat dengan pengawasan orang tua dalam mengerjakan tugas. Kesimpulan jika kita sudah tidak bisa membatasi siswa menggunakan smartphone, maka kita harus mulai mengintegrasikan ke dalam pembelajaran, supaya penggunaan smartphone lebih bermanfaat bagi kehiduoan mereka sebagai siswa.
\end{abstract}

Kata kunci: android, google classroom, penelitian tindakan kelas, motivasi belajar

e-ISSN 2581-1835

p-ISSN 2581-1843 


\section{PENDAHULUAN}

Bahasa Indonesia merupakan salah satu mata pelajaran yang ada di Sekolah Dasar sampai dengan Pendidikan di Perguruan Tinggi, Genre makro yang nantinya diproduksi oleh peserta didik pada saat mereka melanjutkan sekolah yang lebih tinggi berasal dari genre mikro dan sub-sub genre yang mereka dapatkan di Sekolah Dasar. Oleh karena itu dasar-dasar pembelajaran tentang Bahasa Indonesia penting untuk menjadi perhatian guru dan orang tua. Berdasarkan hasil observasi, banyak siswa yang merasa bosan dengan media pembelajaran yang digunakan oleh gurunya terutama di SD Negeri Mertasinga 4 Cilacap. Hal ini tentu saja wajib menjadi perhatian bersama, mengingat motivasi belajar merupakan hal yang penting daam mendukung kesuksesan pembelajaran yang dilakukan oleh guru. Motivasi adalah dorongan tenaga yang dimiliki seseorang untuk mencapai tujuan yang ditetapkan. (Azwar, 2015)

Orang tua saat ini, dituntut untuk ikut terlibat dalam pembelajaran anaknya, supaya orang tua dapat mengontrol anak-anak dalam belajar dengan cara keterlibatan secara aktif baik itu dalam pengambilan keputusan di dalam komite sekolah atau dalam tugas sehari-hari. Kemudian apa saja yang menjembatani antara orang tua dan guru maupun dengan keseluruhan kegiatan sekolah, antara lain; pertemuan dan rapat rutin sekolah, buku komunikasi guru dan orangtua, dan smartphone. Tahun 2019 ini, generasi Alpha yang masih berada di tingkat Sekolah Dasar (SD) sudah banyak yang memiliki smartphone milik pribadi. Untuk itu pihak sekolah sebagai pihak yang sangat berpengaruh terhadap Pendidikan peserta didiknya wajib mengarahkan penggunaan smartphone. Smartphone saat ini merupakan benda yang sudah dimiliki semua orang, yang membedakan hanya spesifikasi dan jenis ditawarkan oleh berbagai macam smartphone yang ditawarkan beberapa merk. Diantara semua merk yang ada, ada aplikasi dalam smartphone yang bernama Google Classroom atau Google Kelas, Google kelas ini dapat digunakan di semua tipe smartphone selama pengguna menggunalan Google mail penggunaan sangat mudah, dapat melakukan kelas siaran langsung, tugas online, dan menampilkan materi di dalamnya.sesuai dengan pendapat berikut "...Google Classroom is considered as one of the best platforms out there for enhancing teachers' workflow. It provides a set of powerful features that make it an ideal tool to use with students" (Iftakhar, S, 2016: 12). Dikatakan disitu bahwa Google Classroom adalah alat ideal yang baik untuk digunakan guru bersama siswa.

Peserta didik di Sekolah Dasar saat ini sudah mengenal Smartphone sejak lahir, merupakan hal yang tidak mungkin apabila kita melarang mereka untuk menggunakannya. Oleh karena itu, di sekolah oleh guru dan di rumah oleh orangtua bersama-sama mengarahkan anak-anak untuk menggunakan smartphone secara bijak. Hal ini juga untuk membiasakan anak-anak memanfaatkan smartphone tidak hanya untuk hiburan tetapi juga untuk belajar Bersama guru dan orangtuanya. Menurut hasil observasi dan wawancara kendala yang 
dihadapi yaitu tidak semua peserta didik memiliki smartphone pribadi, oleh karena itu, guru menyarankan supaya menggunakan smartphone milik orangtua dan penggunaannya adalah untuk Pekerjaan Rumah. Jika ada peserta didik yang memiliki smartphone sendiri juga diperbolehkan, sepanjang ada pengawasan dari orangtua tentang kelas yang mereka miliki di dalam smartphone.

Guru dan orangtua yang berperan aktif dalam pembelajaran peserta didik, dapat memajukan mutu Pendidikan karena sudut pandang yang dapat dijadikan referensi berasal dari berbagai arah. Pengaruh social yang didapatkan peserta didik akan mempengaruhi cara belajarnya. Salah satu hal yang penting dalam pembelajaran yaitu motivasi belajar, motivasi belajar perlu diberi rangsangan dan stimulus secara rutin sehingga peserta didik akan termotivasi baik dari dalam maupun dari luar. Orang dewasa dapat memperkuat kemampuan proporsial seperti membantu dan saling berbagi dan mengesampingkan perilaku antisosial, hal ini yang disebut dengan memperkuat perilaku sosial yang pantas (Slavin, 2011). Jika peserta didik terbiasa dengan perilaku social yang pantas, maka mereka akan selalu menghargai orang-orang yang ada disekitarnya, termasuk bagaimana cara menggunakan berbagai macam metode pembelajaran yang baru.

Beberapa penelitian yang telah dilakukan sebelumnya oleh, Saeed Al Maroof menyatakan dan membuktikan dalam penelitiannya bahwa "... Google classroom can be effective for both the learners and faculty members due to its features. As for the students, it provides a stream line of communication and workflow for students" (2018). Saeed Al Maroof Menyatakan bahwa Google Classroom memiliki fitur-fitur lengkap yang dapat menyediakan jalur komunikasi dan jalur kerja atau tugas bagi siswa lebih efektif.

Pada kenyataan yang dapat kita lihat Bersama, di Indonesia penggunaan smartphone pada umumnya atau Google Classroom pada khususnya masih belum dikenal masyarakat luas, sehingga perlu dikenalkan kepada siswa, orang tua siswa atau wali murid, dan guru mengenai penggunaan smartphone supaya lebih bermanfaat.

\section{METODE}

Metode penelitian yang digunakan adalah Penelitian Tindakan Kelas, Model PTK yang digunakan model Spiral milik Kemmis, Taggart (1988). Permasalahan penelitian di fokuskan kepada penggunaan Google Classroom di dalam kelas untuk meningkatkan motivasi belajar Bahasa Indonesia. Penelitian ini dilakukan dalam dua siklus dan dalam 4 tahap, yaitu 1) refleksi awal, pada tahap ini dilakukan identifikasi masalah berkaitan dengan metode pemberian tugas dan pembelajaran yang dilakukan guru,2) perencanaan tindakan, ditemukan disini bahwa peserta didik kurang termotivasi untuk belajar Bahasa Indonesia, 3) pelaksanaan tindakpan pada kegiatan ini melakukan sosialisasi dan pelatihan kepada guru, orangtua dan siswa tentang penggunaan Google Classroom, 4) kegiatan observasi, refleksi dan evaluasi pada tahap ini 
dilakukan untuk mengumpulkan data menggunakan observasi dilaksanakan dalam dua siklus dan menganalisisnya menggunakan teknik analisis kuantitatif dan Teknik analisi data kualitatif. Aktifitas dalam analisis data yaitu melakukan reduksi data, penyajian data dan menarik kesimpula.

\section{PEMBAHASAN}

Di dalam belajar mengajar, motivasi adalah suatu kondisi atau status internal yang mengarahkan perilaku seseorang. (Wuitt.W, 2001) peranan motivasi intrinsik dan ekstrinsik sangat diperlukan (Sardiman, 2011). Penelitian pada siklus pertama, dilakukan dalam empat tahap, yaitu 1) refleksi awal, 2) perencanaan tindakan, 3) pelaksanaan tindakan dan 4) kegiatan observasi, refleksi dan evaluasi.

\section{Refleksi awal}

Refleksi awal, pada tahap ini dilakukan identifikasi masalah berkaitan dengan metode pemberian tugas dan pembelajaran yang dilakukan guru. Dilakukan observasi dan wawancara di awal mengenai bagaimana motivasi belajar mereka, dengan beberapa hal-hal favorit yang mereka lakukan. Salah satu diantaranya mereka sangat sering menghabiskan waktu bermain smartphone. Hasil dari wawancara dan observasi adalah tidak semua peserta didik memiliki smartphone pribadi, tetapi seluruh orangtua peserta didik memiliki smartphone dan bisa menginstall aplikasi Google Classroom ke dalam smartphone mereka.

2. Perencanaan Tindakan

Pada tahap ini dilakukan pelatihan kepada, peserta didik, guru dan orangtua atau wali murid. Pelatihan sesi pertama khusus untuk guru, yaitu bagaimana membuat kelas, memberikan tugas, memberikan soal evaluasi dan memberikan materi kepada guru. Pelatihan sesi berikutnya untuk peserta didik, dan orangtua atau wali murid, yaitu bagaimana bergabung dalam kelas, melihat tugas yang diberikan guru sampai dengan menupload tugas yang telah selesai dikerjakan.

3. Pelaksanaan Tindakan

Pelaksanaan tindakan pada kegiatan ini adalah guru memulai menggunakan google classroom sebagai sarana pembelajaran di dalam kelas, dimana hari sebelumnya peserta didik dan orangtua atau wali murid sudah diberitahu untuk membawa smartphone, khusus pada pemeblajaran hari tersebut, orangtua atau wali murid ikut belajar di dalam kelas. Kemudian di kelas tersebut juga ada beberapa observer, satu orang observer mengamati 5 pasang peserta didik dan oratua atau wali murid. Kehadiran observer untuk membantu peneliti untuk mengamati. Hadirnya pengamat, pengamatan kepada peserta didik dapat semakin jelas dan detail. (Ibrohim, 2008). Hal ini dapat dijadikan indikator bahwa, monitoring dilakukan dengan baik.

4. Kegiatan Observasi, refleksi dan evaluasi

Pelaksanaan observasi, refleksi dan evaluasi ini dilakukan dengan cara menggunakan bantuan 
observer sebanyak empat orang. Hasil observasi terhadap kegiatan siswa Bersama dengan guru dan orang tua atau wali murid pada siklus pertama adalah motivasi belajar peserta didik masih kurang baik, karena masih kebingungan dalam menggunakan aplikasi Google Classroom.

Pada siklus berikutnya, perencanaan dirubah dengan membuatkan siswa panduan untuk dibawa pulang supaya bekerjasama dengan orang tua masing-masing. Pembuatan email yang digunakan dalam Google Classroom agar pembelajaran menggunakan Google Classroom pada peserta didik di SD dapat berjalan dengan lancar dan dapat meningkatkan motivasi belajar siswa di rumah. Pada pelaksanaan tindakan didokumentasikan untuk melihat pengaruh perilaku siswa terhadap refleksi.

\section{Refleksi awal}

Refleksi awal pada siklus kedua, disiapkan panduan yang dapat digunakan oleh guru, peserta didik dan orangtua atau wali murid untuk menggunakan aplikasi Gogle Classroom. pada tahap ini dilakukan identifikasi masalah berkaitan dengan penggunaan aplikasi Google Classrom untuk pekerjaan rumah.

2. Perencanaan Tindakan

Pada tahap ini dilakukan yang kedua kalinya, pelatihan dibuat menjadi 2 sesi. Sesi yang pertama untuk guru, sesi yang kedua untuk peserta didik didampingi oleh orangtua atau wali murid. Kali ini pelatihan tidak hanya menggunakan pendampingan tetapi juga menggunakan panduan yang telah disusun dan disediakan untuk guru, peserta didik dan orangtua atau wali murid yang ada, dilakukan kepada 1 guru, 20 orang peserta didik dan 20 orang tua atau wali murid yang mendamping. Diharapkan peserta didik dan orangtua atau wali murid ini dapat mengerjakan sendiri Pekerjaan Rumahnya.

3. Pelaksanaan Tindakan

Pelaksanaan tindakan pada kegiatan di sesi ke dua ini sama dengan sesi pertama. Guru memulai menggunakan google classroom sebagai sarana pembelajaran di dalam kelas, dimana hari sebelumnya peserta didik dan orangtua atau wali murid sudah diberitahu untuk membawa smartphone, khusus pada pemeblajaran hari tersebut, orangtua atau wali murid ikut belajar di dalam kelas. Kemudian di kelas tersebut juga ada beberapa observer, satu orang observer mengamati 5 pasang peserta didik dan oratua atau wali murid. Kehadiran observer untuk membantu peneliti untuk mengamati. Hadirnya pengamat, pengamatan kepada peserta didik dapat semakin jelas dan detail. (Ibrohim, 2008). Hal ini dapat dijadikan indikator bahwa, monitoring dilakukan dengan baik.

4. Kegiatan Observasi, refleksi dan evaluasi

Pelaksanaan observasi, refleksi dan evaluasi ini dilakukan dengan cara yang sama pada seperti pada siklus 1, menggunakan bantuan observer sebanyak empat orang. Hasil observasi terhadap kegiatan siswa Bersama dengan guru dan orang tua atau wali murid pada siklus kedua ini adalah motivasi belajar peserta didik mengalami peningkatan, sudah mendapatkan 
penjelasan tutorial dan panduan

cara menggunakan aplikasi

Google Classroom.

Perbandingan antara siklus 1 dan siklus 2 dapat dilihat dalam table berikut. Diukur berdasarkan aspek aspek motivasi belajar menurut Sudjana (2009)

Tabel 1. Rata-rata Skor Observasi Motivasi Belajar

\begin{tabular}{|l|r|r|r|}
\hline No & Aspek & Siklus 1 & Siklus 2 \\
\hline 1 & Perhatian dan minat siswa terhadap Pekerjaan Rumah & 8.71 & 9.95 \\
\hline 2 & $\begin{array}{l}\text { Usaha siswa untuk melakukan tugas-tugas belajarnya } \\
\text { Tanggung jawab siswa dalam melakukan tugas-tugas } \\
\text { belajarnya }\end{array}$ & 11.13 & 11.73 \\
\hline 4 & $\begin{array}{l}\text { Rasa senang mengerjakan tugas dari guru menggunakan } \\
\text { Google Classroom }\end{array}$ & 14.11 & 15.22 \\
\hline 5 & $\begin{array}{l}\text { Reaksi yang ditunjukan siswa terhadap stimulus dari guru } \\
\text { menggunakan Google Classroom }\end{array}$ & 9.56 & 10.45 \\
\hline
\end{tabular}

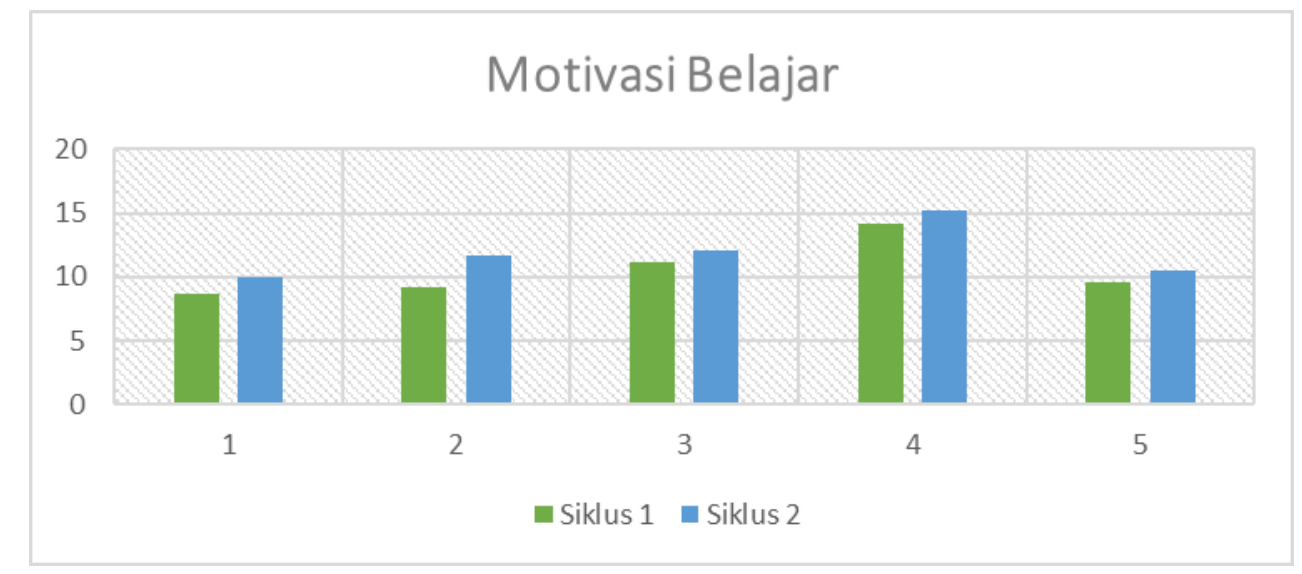

Gambar 1. Hasil Observasi Motivasi Belajar

Penelitian Tindakan Kelas ini meningkat sebesar 24,48\%, aspek dilakukan melalui dua siklus ketiga tentang tanggung jawab siswa menggunakan observasi. Untuk dalam melakukan tugas-tugas mengetahui peningkatan motivasi belajarnya meningkat sebesar $8,8 \%$, belajar setelah menggunakan Google aspek keempat tentang rasa senang Classroom, dilihat dari lima aspek mengerjakan tugas dari guru dalam dua siklus yang sudah menggunakan Googe Classroom dilakukan. Aspek yang pertama meningkat sebanyak $1,11 \%$ dan tentang perhatian dan minat siswa aspek yang kelima tentang reaksi terhadap pekerjaan rumah mengalami yang ditunjukan siswa terhadap peningkatan sebesar $12,4 \%$, aspek stimulus dari guru menggunakan kedua tentang usaha siswa untuk Google Classroom meningkat melakukan tugas-tugas belajarnya sebanyak $8,9 \%$. Hal tersebut 


$\begin{array}{llrlr}\text { membuktikan } & \text { bahwa } & \text { Penelitian } & \text { smartphone dapat meningkatkan } \\ \text { Tindakan } & \text { Kelas } & \text { ini } \begin{array}{l}\text { dapat } \\ \text { motivasi belajar siswa }\end{array} & \\ \text { membuktikan bahwa penggunaan } & & \end{array}$

\section{SIMPULAN}

Simpulan dari penelitian ini adalah, penggunaan Google Classroom dapat meningkatkan motivasi belajar siswa, karena pembelajaran yang lebih menarik dan dibantu orang tua di rumah. Penelitian tetap dilakukan di ruang kelas, untuk selanjutnya penggunaan Google
Classroom ini digunakan di rumah. Guru, peserta didik dan orangtua saling berhubungan untuk Bersamasama melakukan Pekerjaan Rumah peserta didik, sehingga dapat dipastikan peserta didik mendapatkan perhatian kebih dari orang tuanya.

\section{DAFTAR PUSTAKA}

Azwar, S (2015). Sikap Manusia, Teori dan Pengukurannya. Jogjakarta: Pustaka Pelajar Offset.

Ibrohim (2009). Pengaruh Model Implementasi Lesson Study Dalam kegiatanMGMP Terhadap Peningkatan Kompetensi Guru dan Hasil Belajar Biologi Siswa. Disertasi tidak diterbitkan. Malang:PPS Universitas Negeri Malang.

Iftakhar, S (2016). Google Classroom: What Works and How?. Journal of Education and Social Sciences, Vol. 3, 12-18.

Kemmis, Stephen., Taggart, R.M (1988). The Action Research Planner. Australia: Deakin University Press.
Saeed Al Maroof, R.A (2018). Students Acceptance of Google Classroom: An Exploratory Study using PLS-SEM Approach. I-jet. Vol 6. 112-123.

Sudjana, N (2009). Penilaian Hasil Proses Belajar Mengajar. Bandung: Remaja Rosda Karya.

Sardiman, A.M (2011). Interaksi dan Motivasi Belajar Mengajar. Jakarta: Rajawali Press

Slavin, R (2011). Educational Psycholoh: Theori and Practice. Pearson Education. New Jersey. Wuitt, W. (2001). Motivation To Learn. An Overview. Educatinal Psychology Interactive. Valdosta: Saldosta State University. 